\title{
Hubungan Tingkat Kelebihan Berat Badan dengan Uji Toleransi Glukosa Oral pada Siswa SMP di Kota Padang
}

\author{
Eka Agustia Rini, IGM Afridoni A \\ Bagian Ilmu Kesehatan Anak Fakultas Kedokteran Universitas Andalas/RS Dr. M. Djamil Padang
}

\begin{abstract}
Latar belakang. Obesitas pada anak merupakan masalah gizi dan sukar diatasi. Peningkatan obesitas pada anak dan remaja menimbulkan peningkatan insiden diabetes melitus tipe 2. Pemeriksaan uji toleransi glukosa oral dapat digunakan untuk mendeteksi gangguan metabolik.

Tujuan. Mengetahui hubungan derajat obesitas dengan uji toleransi glukosa oral (TTGO) pada siswa SMP di kota Padang.

Metode. Penelitian dilakukan Juli - September 2006 terhadap 109 siswa SMP kota Padang. Subjek terdiri dari 2 kelompok yaitu overweight (indeks massa tubuh (IMT) p=85-95) dan obesitas (IMT p >95). Dilakukan pengukuran berat badan, tinggi badan, gula darah puasa dan gula darah 2 jam posprandial. Data dianalisis dengan uji $t$-test, chi-square dan korelasi dengan tingkat kemaknaan $\mathrm{p}<0,05$.

Hasil. Didapatkan 10,1\% siswa kelebihan berat badan, overweight 6,1\% dan obesitas 4,0\%. Berat badan siswa overweight berkisar (44,0-74,0) kg. IMT 2(1,6-27,8) $\mathrm{m}^{2}$. Berat badan siswa obesitas berkisar $(55,5-$ $96,0) \mathrm{kg}$, IMT $(24,6-42,9) \%$. Tidak terdapat perbedaan rerata gula darah antara kelompok overweight dengan obesitas (p 0,146). Begitu juga rerata gula darah 2 jam posprandial ( $p=0,26)$. Pada obesitas $3(2,7 \%)$ kasus dengan uji toleransi glukosa (TGT). Terdapat hubungan lemah antara berat badan dengan kadar gula darah puasa $(\mathrm{p}=0,045 ; \mathrm{r} 0,192)$

Kesimpulan. Tidak didapatkan hubungan antara kelebihan berat badan dengan uji toleransi glukosa (Sari Pediatri 2008;9(6):417-22).
\end{abstract}

Kata kunci: obesitas, uji toleransi glukosa

Alamat korespondensi

Dr. Eka Agustia Rini, Sp.A., Divisi Endokrinologi. Bagian Ilmu Kesehatan Anak, Fakultas Kedokteran Universitas Andalas, Jl Perintis Kemerekaan RS Dr. M. Djamil, Padang. Telp. 0751-37913

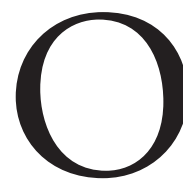

besitas merupakan keadaan patologik akibat penumpukan lemak yang berlebihan secara menyeluruh di bawah kulit dan jaringan lainnya di dalam tubuh. Obesitas dapat timbul kapan saja, namun lebih 
sering pada tahun pertama usia kehidupan, usia 5-6 tahun dan selama masa remaja. ${ }^{1}$ Obesitas pada anak menjadi masalah gizi global saat ini dan merupakan masalah klinik yang sukar diatasi. Etiologi obesitas multifaktorial, satu sama lainnya saling mempengaruhi. ${ }^{2,3}$

Data National center for health statistics (NCHS) menunjukkan bahwa hampir 1 dari 5 anak di Amerika Serikat mengalami kelebihan berat badan, prevalensinya terus meningkat dalam 20 tahun terakhir. Peningkatan angka obesitas anak juga terjadi di Inggris, Jepang, di beberapa negara sedang berkembang, bahkan seluruh dunia. ${ }^{4}$ Di Indonesia prevalensi obesitas menurut data Survei Sosial Ekonomi Nasional (SUSENAS) menunjukkan peningkatan baik di perkotaan maupun di pedesaan. Di perkotaan pada tahun 1989 didapatkan prevalensi obesitas 4,6\% pada laki-laki dan 5,9\% pada perempuan, sedangkan pada tahun 1992 didapatkan 6,3\% dan 8\% pada perempuan. Prevalensi obesitas tahun 1995 pada 27 propinsi 4,6\%. ${ }^{5}$ Pada tahun 1995 diperkirakan terdapat 200 juta kasus obesitas dewasa di seluruh dunia, 18 juta di antaranya adalah anak balita, sehingga WHO menyatakan obesitas sebagai masalah global (global pandemic) ${ }^{6}$

Obesitas pada anak dan remaja dapat menimbulkan gangguan pada berbagai organ tubuh. Beberapa keadaan yang dapat timbul akibat obesitas adalah hipertensi, hiperlipidemia, meningkatnya risiko penyakit jantung koroner dan diabetes melitus (DM). ${ }^{7}$ The bogalusa heart study melaporkan bahwa kadar gula darah dan insulin puasa berhubungan dengan tekanan darah, ukuran tubuh dan kardiovaskular pada anak usia 5 sampai dengan 17 tahun. $^{8}$

Meningkatnya obesitas pada anak dan remaja pada dekade terakhir menimbulkan peningkatan insiden diabetes melitus tipe 2 pada anak dan remaja. Penelitian Steinberger, ${ }^{9}$ mendapatkan bahwa 22\%$25 \%$ anak dan remaja dengan obesitas berat merupakan prediabetik ditandai dengan tanda gangguan terhadap uji toleransi glukosa.

Penelitian mengenai hubungan obesitas dengan faktor risiko terjadinya kelainan kardiovaskular telah diteliti di kota Padang. Penelitian Gustina ${ }^{10,11}$ di beberapa SD favorit di kota Padang mendapatkan terdapat hubungan antara lingkar pinggang anak obesitas dengan risiko terjadinya kelainan kardiovaskular. Susanti ${ }^{12}$ mendapatkan 7,4\% siswa SMP SMA di kota Bogor mengalami gangguan toleransi glukosa. Pribadi (2002) mendapatkan 3\% siswa SMP di kota Bandung mengalami toleransi glukosa terganggu. ${ }^{13}$ Melihat hasil penelitian tersebut gangguan TGT pada remaja di kota Padang mungkin juga sudah terjadi.

\section{Metode}

Penelitian cross sectional study telah dilakukan pada empat Sekolah Menengah Pertama (SMP) di kota Padang, pada bulan Mei sampai dengan September 2006. Populasi penelitian siswa SMP di kota Padang yang mengalami overweight dan obesitas. Subjek penelitian dipilih secara konsekutif, mewakili daerah urban dan sub-urban. Kriteria inklusi penelitian adalah siswa SMP di kota Padang dan mengalami kelebihan berat badan (overweight atau obesitas). Penelitian diawali dengan pengajuan izin ke Dinas Pendidikan Nasional Kebudayaan kota Padang dan kepala sekolah tempat penelitian akan dilakukan. Dilakukan sosialisasi tentang obesitas dan tujuan penelitian terhadap guru dan siswa SMP. Kepada siswa diberikan lembaran informed consent yang harus diisi oleh orang tua.

Pemeriksaan fisik yang dilakukan adalah,

1. Berat badan semua siswa ditimbang menggunakan alat Detecto dengan kapasitas sampai $200 \mathrm{~kg}$ dan akurasi sampai $0,1 \mathrm{~kg}$. Siswa ditimbang tanpa menggunakan sepatu atau alas kaki dan hanya memakai pakaian sekolah sehari-hari saja. Pengukuran dilakukan oleh peneliti atau orang yang telah dilatih sebelumnya (yakni mahasiswa kedokteran yang khusus dilatih untuk penelitian), dilakukan 3 kali pemeriksaan untuk setiap anak. Hasil pengukuran diambil angka rata-rata dari 3 kali pengukuran tersebut.

2. Tinggi badan siswa diukur menggunakan alat Staturemeter dengan akurasi $1 \mathrm{~mm}$. Diukur pada posisi tegak dengan muka lurus menghadap ke depan, bokong, tumit menempel ke dinding dan alas kaki dibuka. Pengukuran dilakukan oleh peneliti atau orang yang telah dilatih oleh peneliti (yakni mahasiswa kedokteran yang khusus dilatih untuk penelitian ini) dan dilakukan sebanyak 3 kali. Hasil pengukuran diambil angka rata-rata dari 3 kali pengukuran tersebut.

3. Indeks masa tubuh (IMT) ditentukan dengan menggunakan rumus $\mathrm{BB} /(\mathrm{TB})^{2}$ 
4. Berdasarkan indeks masa tubuh siswa dikelompokkan menjadi 2 kelompok, kelompok siswa overweight dan obesitas.

Kepada siswa yang obesitas dan overweight diberikan lagi informed consent untuk pengambilan sampel darah untuk pemeriksaan TTGO dan formulir penelitian untuk diisi.

Sebagai persiapan untuk pengambilan sampel darah subjek penelitian dianjurkan untuk makan dengan jumlah karbohidrat yang cukup selama 3 hari (paling kurang 150-200 g per hari). Pada malam hari sebelum pengambilan sampel, mulai pukul 00.00 WIB subjek tidak boleh makan dan hanya diperbolehkan minum air putih. Setelah puasa 8 jam dimulai pengambilan sampel darah puasa $(0$ menit) kemudian subjek minum larutan glukosa 75 gram dalam $300 \mathrm{cc}$ air dalam waktu 5 menit. Selanjutnya subjek diambil sampel darahnya pada menit ke 120 setelah minum glukosa. Darah yang diambil adalah darah vena. Pengambilan darah dilakukan oleh peneliti atau orang yang terlatih untuk melakukan pengambilan darah vena. Kemudian sampel darah diperiksa kadar gula darahnya dengan alat Cobasmira yang menggunakan tehnik fotometer dengan alat HITACHI. Data analitik diolah dengan menggunakan uji khi kuadrat, uji $t$-test dan analisis regresi. Derajat kemaknaan $\mathrm{p}<0,05$. Program yang digunakan SPSS versi 12.0

\section{Hasil}

Penelitian dilakukan terhadap 3536 siswa pada 4 SMP di Kota Padang yang mewakili daerah urban dan sub urban yaitu SMP Negeri 2, SMP Negeri 4, SMP Negeri 10 dan SMP Negeri 24 Padang. Didapatkan 359 $(10,1 \%)$ orang siswa yang mengalami overweight dan obesitas, terdiri dari 214 (58,6\%) overweight dan 148(41,4\%) obesitas. Dari 214 siswa dengan overweight $81(37,9 \%)$ laki-laki dan $133(62,1 \%)$ perempuan. Siswa dengan obesitas terdiri dari $92(62,1 \%)$ laki-laki dan 56(37,9\%) perempuan.

Dari 359 siswa tersebut hanya 136 yang bersedia mengikuti penelitian. Dua puluh tujuh dikeluarkan dari penelitian karena tidak memenuhi syarat penelitian di antaranya adalah 10 siswa muntah setelah minum glukosa 75 gram (air tidak dihabiskan), 12 menolak untuk pengambilan darah, 5 makan nasi setelah darah yang pertama diambil.
Didapatkan perbedaan umur yang bermakna antara kelompok overweight dan obesitas dengan $p$ 0,005 (Tabel 1). Pada kelompok overweight terdiri dari perempuan $54,6 \%$ sedangkan laki-laki 44,8\%. Berat badan berkisar antara 44,0-74,0 kg (rerata 56,38 SB 7,18). Pada kelompok obesitas laki-laki 55,2\% dan perempuan $45,1 \%$. Berat badan berkisar antara $55,5-$ $96,0 \mathrm{~kg}$ (rerata 68,06 SB 8,98).

Indeks massa tubuh pada kelompok overweight berkisar antara 21,6-27,8 (rerata 24,38 SB 1,49), terbanyak persentil 90>p $\leq 95$ sebesar 59,3\% (Tabel 2). Pada kelompok obesitas indeks massa tubuh berkisar antara 24,6-42,9 (rerata 28,89 SB 3,16), terbanyak persentil $\geq 97$.

Pada pemeriksaan gula darah puasa, tidak terdapat perbedaan rerata gula darah antara kelompok overweight dengan obesitas (p 0,146), begitu pada rerata gula darah 2 jam posprandial (p 0,26) (Tabel $3)$. Setelah 2 jam posprandial terdapat 3(2,7\%) dari siswa obesitas dengan TGT, gula darah berkisar 141$152 \mathrm{mg} \%$, berat badan berkisar $64,5-77 \mathrm{~kg}$, usia berkisar 12,4-13 $\mathrm{kg}$ dan IMT berkisar 26,8-30,5

Tabel 1. Karakteristik subjek penelitian

\begin{tabular}{lccc}
\hline Karakteristik & Overweight & Obesitas & $p$ \\
\hline Jumlah (\%) & $54(49,5)$ & $55(50,5)$ & \\
Jenis kelamin & & & \\
$\quad$ Laki-laki (\%) & $26(44,8)$ & $32(55,2)$ & $0,294^{*}$ \\
$\quad$ Perempuan (\%) & $28(54,9)$ & $23(45,1)$ & \\
Usia (tahun) & $13,6 \pm 1,02$ & $13,1 \pm 0,96$ & $0,005^{* *}$ \\
$\quad$ Kisaran & $11,10-15,8$ & $11,3-15,7$ & \\
Berat badan (kg) & $56,38 \pm 7,18$ & $68,06 \pm 8,98$ & $0,000^{* *}$ \\
$\quad$ Kisaran & $44,0-74,0$ & $55,5-96,0$ & \\
\hline
\end{tabular}

${ }^{*}$ Uji chi square ${ }^{* *} \mathrm{Uji}$ t-test

Tabel 2. Indeks masa tubuh pada kelompok overweight dan obesitas

\begin{tabular}{lccc}
\hline & Overweight & Obesitas & $p$ \\
\hline IMT & $24,38 \pm 1,49$ & $28,89 \pm 3,16$ & $0,000^{*}$ \\
Kisaran & $21,6-27,8$ & $24,6-42,9$ & \\
& & & \\
$85>\mathrm{p} \leq 90$ & $22(40,7 \%)$ & & \\
$90>\mathrm{p} \leq 95$ & $32(59,3 \%)$ & & \\
$95>\mathrm{p} \leq 97$ & & $17(31,5 \%)$ & \\
$\geq 97$ & & $38(68,5 \%)$ & \\
\hline
\end{tabular}

* Uji t-test 
(Tabel 4 dan 5). Tidak ada yang menderita diabetes melitus tipe 2. Pada kelompok overweight tidak ada siswa yang mengalami TGT maupun diabetes melitus tipe 2.

\section{Diskusi}

Didapatkan 10,1\% siswa SMP di kota Padang mengalami kelebihan berat badan, terdiri dari 6,1\% overweight dan $4,0 \%$ obesitas. Temuan ini lebih rendah dari penelitian Susanti ${ }^{12}$ yaitu 17,4\% dari siswa SMP dan SMU Regina Pacis Bogor mengalami kelebihan berat badan, terdiri dari $11 \%$ overweight dan $6,4 \%$ obesitas. Di Amerika Serikat tahun 1988-1994 didapatkan 20\% anak usia 12-19 tahun mengalami overweight dan $8 \%-17 \%$ mengalami obesitas. ${ }^{14}$ Kejadian overweight lebih banyak terdapat pada perempuan, tetapi kejadian obesitas lebih banyak pada laki-laki. Susanti ${ }^{12}$ di Bogor tahun 2002, Meilany ${ }^{15}$ di Jakarta tahun 2002, dan Pribadi ${ }^{13}$ di Bandung tahun 2002 juga mendapatkan obesitas lebih banyak pada siswa laki-laki.

Setelah 2 jam posprandial juga tidak didapatkan perbedaan rerata gula darah antara kelompok overweight dan obesitas. Penelitian Susanti ${ }^{12}$ ataupun Meilany ${ }^{15}$ mendapatkan kadar gula darah pada kelompok obesitas lebih tinggi dibanding dengan kelompok overweight. ${ }^{12,13}$ Tiga siswa $(2,7 \%)$ dari kelompok obesitas mengalami toleransi glukosa terganggu (kadar gula darah 141-152 mg\%) dan tidak didapatkan siswa yang menderita diabetes melitus tipe 2. Dua dari siswa TGT tersebut berasal dari keluarga dengan diabetes melitus dan mempunyai indeks masa tubuh persentil $>97$. Kasus yang ketiga tidak mempunyai riwayat diabetes melitus dalam keluarga dan mempunyai indeks massa tubuh persentil 9597.

Susanti ${ }^{12}$ dan Pribadi ${ }^{13}$ mendapatkan siswa yang mengalami TGT masing-masing 7,8\% dan 7,6\%, sedangkan penelitian-penelitian di luar negeri mendapatkan hasil yang lebih tinggi. Sinha ${ }^{16}$ di Amerika Serikat mendapatkan 21\% remaja obesitas usia 11-18 tahun mengalami toleransi glukosa terganggu dan $4 \%$ mengalami diabetes tipe 2 . Penelitian Grinstein ${ }^{17}$ mendapatkan angka $11 \%$ remaja mengalami toleransi glukosa terganggu dan $8 \%$ diabetes tipe 2. Penelitian Weigand ${ }^{18}$ di Jerman mendapatkan hasil yang lebih tinggi yakni 36,3\% anak-anak dan remaja mengalami toleransi glukosa terganggu dan 5,9\% mengalami diabetes tipe 2 . Penelitian Sinha, ${ }^{16}$ Grinstein $^{17}$ dan Weigand ${ }^{18}$ mendapatkan bahwa perbedaan ras merupakan salah satu faktor yang mempengaruhi terjadinya toleransi glukosa. Ras kulit hitam di Amerika sangat berisiko tinggi untuk mengalami toleransi glukosa terganggu dan diabetes tipe 2. Sementara di Eropa ras Kaukasus yang sangat berisiko menderita gangguan toleransi

Tabel 3. Kadar rerata gula darah pada kelompok overweight dan obesitas

\begin{tabular}{lccc}
\hline Kadar gula darah & Overweight & Obesitas & $p$ \\
\hline Gula darah puasa $(\mathrm{mg} \%)$ & $70,54 \pm 11,41$ & $73,71 \pm 11,23$ & $0,146^{*}$ \\
Kisaran $(\mathrm{mg} \%)$ & $44-97$ & $58-100$ & \\
Gula darah 2 jam pp $(\mathrm{mg} \%)$ & $104,26 \pm 16,45$ & $111,40 \pm 16,56$ & $0,26^{*}$ \\
Kisaran $(\mathrm{mg} \%)$ & $70-137$ & $72-152$ & \\
\hline
\end{tabular}

* Uji t-test

Tabel 5. Kadar rerata gula darah berdasarkan uji toleransi glukosa

\begin{tabular}{lccc}
\hline \multirow{2}{*}{ Kadar gula darah } & \multicolumn{2}{c}{ Toleransi glukosa } & \multirow{2}{*}{$p$} \\
\cline { 2 - 3 } & Normal & Terganggu & \\
\hline Gula darah puasa $(\mathrm{mg} \%)$ & $71.95 \pm 11,39$ & $77.67 \pm 13,87$ & $0,396^{*}$ \\
Kisaran & $51-100$ & $66-93$ & \\
Gula darah 2 jam pp $(\mathrm{mg} \%)$ & $106.80 \pm 15,78$ & $145.33 \pm 5,86$ & $0,002^{*}$ \\
Kisaran & $70-137$ & $141-152$ & \\
\hline
\end{tabular}

* Uji t test 
glukosa. ${ }^{19}$ Penelitian Sasaki di Jepang mendapatkan $14,8 \%$ remaja mengalami diabetes tipe 2 dan 10,5\% mengalami toleransi glukosa terganggu. ${ }^{20}$ Penelitian Chow CC. $\mathrm{dkk}^{21}$ di Hongkong mendapatkan remaja obesitas dengan toleransi glukosa terganggu sebesar 21\% dan 6,5\% mengalami diabetes.

Peneliti mendapatkan hasil toleransi glukosa terganggu yang lebih rendah daripada penelitian lain di luar negeri, bahkan juga lebih rendah dari hasil penelitian yang dilakukan di Indonesia. Perbedaan ini kemungkinan karena randomisasi sampel tidak dilakukan karena ini diambil secara konsekutif mengingat banyak siswa yang menolak mengikuti penelitian, jumlah sampel lebih kecil jika dibanding dengan hasil penjaringan, dan diadakan di daerah sub urban dan urban yang mewakili kota Padang.

Penelitian Sinha ${ }^{16}$ dan berbagai penelitian lainnya di luar negeri juga mendapatkan bahwa pemeriksan 2 jam posprandial lebih sensitif untuk mendeteksi diabetes secara dini dibandingkan dengan pemeriksaan gula darah puasa saja. Dijumpai gangguan kadar gula darah puasa merupakan indikasi terjadinya diabetes tipe 2.

Pada remaja dengan gangguan toleransi glukosa dijumpai laki-laki lebih banyak dibandingkan dengan perempuan, namun perbedaan ini tampak tidak begitu nyata karena proporsi subjek laki-laki obesitas lebih banyak dari perempuan.

Dinilai terdapat hubungan lemah antara berat badan terhadap kadar gula darah, namun tidak didapatkan hubungan antara berat badan dengan kadar gula darah 2 jam posprandial. Pada penelitian Susanti ${ }^{12}$ terdapat hubungan antara kadar gula darah dengan berat badan.

Toleransi glukosa terganggu pada kelompok obesitas, namun tidak terjadi pada siswa dengan berat badan yang terberat. Penelitian Susant ${ }^{12}$ mendapatkan 10 orang subjek penelitiannya mengalami gangguan toleransi glukosa, 6 orang berasal dari kelompok overweight dan 4 orang dari kelompok obesitas. Penelitian Pribadi ${ }^{13}$ mendapatkan $2(3 \%)$ orang mengalami gangguan toleransi glukosa terganggu, keduanya pada kelompok obesitas.

\section{Daftar Pustaka}

1. Donohoue PA. Obesity. Dalam: Nelson WE, Behrman RE, Kliegman RM, Arvin AM, penyunting. Textbook of pediatrics. Edisi ke-17. Philadelphia: Saunders; 2000. h. 177-9.

2. Soetjiningsih. Obesitas Pada Anak. Dalam Soetjiningsih, Ranuh G, penyunting. Tumbuh Kembang Anak. Jakarta: EGC; 1995:183-90.

3. Sjarif DR. Obesitas pada Anak dan Permasalahannya. Dalam Trihono PP, Syarif DR, Hegar B, dkk, penyunting. Hot Topics in Pediatrics II Pendidikan Kedokteran Berkelanjutan Ilmu Kesehatan Anak XLV, Jakarta 18-19 Februari 2002. Jakarta: Ikatan Dokter Anak Indonesia; 2002. h. 219-32.

4. Miller J, Rosenbloom A, Silverstein J. Childhood obesity. J Clin Endocrinol Metab 2004;89:4211-18

5. Lailani D, Hakimi. Pertumbuhan fisik anak obesitas. Sari Pediatri 2003;5:99-102

6. Bougneres P. Genetics of obesity and type 2 diabetes tracking pathogenic traits during the predisease period. Diabetes 2002;51(Suppl 3):S295-303.

7. Pozzan R, Brandao AA, Da Silva SL. Hyperglycemia, hyperinsulinemia, overweight and high blood presure in young adults. Hypertension 1997;30:650-7.

8. Freedman DS, Dietz WH, Srinvasan SR, Berenson GS. The relation of overweight to cardiovascular risk factors among children and adolescents: the bogalusa heart study. Pediatrics, 1999;103:1175-82.

9. Steinberger J, Daniels SR. Obesity, Insulin resistance, diabetes and cardiovascular risk in children an American heart association scientific statement from the atherosclerosis, hypertension and obesity in the young committee (council on cardiovascular disease in the young) and the diabetes committee (council on nutrition, physical activity, and metabolism). Circulation 2003; 107:1448-53.

10. Lubis G, Oyong N. Hubungan lingkar pinggang dengan faktor risiko penyakit kardiovaskuler pada anak obesitas usia Sekolah Dasar. Sari Pediatri 2006;8:147-53.

11. Andesta D. Prevalensi dan faktor yang berhubungan dengan obesitas pada siswa Sekolah Dasar Favorit di Kota Padang. Tesis. Padang: Universitas Andalas, 2004.

12. Susanti FS. Tes toleransi glukosa oral pada anak dengan obesitas. Tesis. Jakarta: Universitas Indonesia, 2002.

13. Pribadi A, Subardja D, Fadil R. Relationship between the degree of obesity and oral glucosa in primary obese adolescent. Paediatrica Indonesia 2002;42:249-53.

14. Sasaki N, Kobayashi K, Kida K. Assessment of OGTT in Japanese children based on new diagnostic criteria of diabetes mellitus. Disampaikan pada Joint Pediatrics Endocrinology Meeting, Montreal, Kanada, 7-9 Juli 2001. 
15. Meilany TA. Profil klinis, laboratoris serta sikap dan perilaku siswa sekolah dasar dengan obesitas. Studi kasus di SD Tarakanita 5, SDI Al Azhar Rawamangun dan SDI Al Azhar Kelapa Gading Jakarta. Tesis. Jakarta: Universitas Indonesia, 2002.

16. Sinha R, Fisch G, Teague B. Prevalence of impaired glucose tolerance among children and adolescents with marked obesity. N Engl J Med 2002;346(11):802-10.

17. Sokol RJ. The chronic disease of childhood obesity: the sleeping giant has awakened. Editorials. J Pediatrics 2000;136:711-3

18. Wiegand S, Maikowski U, Blankenstein O. Type 2 Diabetes and impaired glucose tolerance in european chil- dren and adolescents with obesity-a problem that is no longer restricted to minority groups. Eje 2004;151:199206.

19. Hamiel OP, Zeitler P. Type 2 Diabetes in adolescents, no longer rare. Pediatric in review 1998; 1:434-5.

20. Sokol RJ. The chronic disease of childhood obesity: the sleeping giant has awakened. Editorials. J Pediatrics 2000;136:711-3

21. Chow CC, Ko GTC, Li JKy. Two-hour post-glucose loading plasma glucose is the main determinant for the progression from impaired glucose tolerance to diabetes in Hongkong Chinese. Letter. Diabetes Care 1999; 22:2096-7 